\title{
Cisinta
}

\section{Implementation of Product Sales Forecast Using A trtificial Neural Network Method}

\author{
Cholid Fauzi ${ }^{1}$, Aly Dzulfikar ${ }^{2}$ \\ ${ }^{1}$ Politeknik Negeri Bandung \\ ${ }^{2}$ Universitas Nurtanio \\ ${ }^{1}$ cholid.fauzi@polban.ac.id*; ${ }^{2}$ dzulfikar@gmail.opm
}

\begin{abstract}
Product sales forecasting is used by companies to estimate or predict future sales levels using sales data in the previous year. The Artificial Neural Network Backpropagation Algorithm can forecast the sales of goods for the next period for each item in the company. The forecasting process begins by determining the variables needed in the network pattern, and then the established network pattern continued in the network training process using the backpropagation algorithm. After carrying out the network training process, the researcher comparisons with several network patterns formed. This research was conducted to discuss the forecasting analysis of $P T X Y Z$ products on spiral and leaf springs. Forecasting carried out on Toyota 48210-25290 R3 type leaf springs using the Artificial Neural Network Backpropagation method with a learning rate weight value of 0.1 hidden layers four and an error of 0.01. From the data processing analysis that has been carried out based on the weight parameters selected, the prediction of sales in April.
\end{abstract}

Keywords: Sales Forecasting, Artificial Neural Network, Prediction, Backpropagation

\section{Introduction}

PT. XYZ is a manufacturer of car springs equipment that sells both retail and wholesale. PT. XYZ itself more or less has about 50 products per. PT. XYZ markets its products to distributors spread across several regions in Indonesia. These distributors serve customers directly, so the existence of these distributors has a significant role in determining future business strategies. Based on the results of interviews with PT. XYZ that the product distribution process was carried out after the distributor asked PT. XYZ. Then the product will be distributed to distributors depending on the inventory in the warehouse. Product distribution to distributors depends on product inventory in the warehouse, so PT XYZ needs to predict sales of goods in the following month. Prediction is an essential part of every business company in making management decisions. Prediction is the process of using past data from a variable or set of variables to estimate future values. Product sales prediction is used by companies to estimate or predict sales by using sales data in the previous year. Various prediction models have progressed quite rapidly, one of which is an Artificial neural network used by researchers and recognizes historical data patterns, which can predict a problem. The application of artificial neural networks in the field of forecasting and prediction has been in almost all scientific studies in recent years because it has better accuracy than statistical and mathematical models besides that Artificial Neural Networks have flexibility, both in design and use [1]. Based on the description above, this writer focuses on the naive Bayes classifier method, which is implemented to predict product sales of PT. XYZ. This study uses an artificial neural network with the backpropagation method because of its simplicity and good performance. The backpropagation algorithm has a way of working by adjusting the interconnected weights between neurons to achieve a minimum error between the predicted output and the actual output [2]. This artificial neural network backpropagation 
has other advantages than other ANN methods, namely ANN biekpropagatưon ising

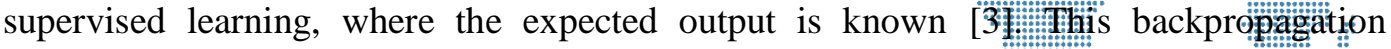
artificial neural network can be used to solve problems in various

\section{Research Methodology}

This research approach to the stages in the ANN and is combined with software development. The following steps :

a. Business Process Analysis

At this stage, the data used is obtained from data on the number of sales of PT. XYZ products.

b. Literature Study

Literature study is the first step in this research, and this literature study was conducted to complete the basic knowledge and theories used in this research. The literature study used comes from books, journals, and seminars

c. Identifying Problems

At this problem identification stage, it is carried out after all the data is met, and then the appropriate dataset is obtained to be processed at the conversion stage of the data obtained following the specified weight.

d. Preprocessing

The steps taken are to make changes to several data types in the dataset attributes to make it easier to understand the record contents and make selections by paying attention to data consistency.

e. Determining Pattern

The results of this stage are several artificial neural network models with the Backpropagation method to determine patterns.

f. Testing the Results of Data Processing

After the pattern determination process is complete, a trial phase is carried out on data processing results using Matlab R2011b Software and exported to CSV.

g. Predicting

Prediction is made to compare the number with the most accurate Backpropagation algorithm model.

h. Final Evaluation

The final evaluation is done to determine whether the testing of data processing results is as expected.

The method used is the ANN backpropagation method. The stage is to enter product sales data at PT XYZ before, then the data that has been entered is processed so that later it can display product sales predictions at PT XYZ in the future. In the software to predict product sales at PT XYZ that will be built, there are two user roles: Administrator and Owner.

Here's the process of how the software works for Administrators:

1. Administrators are asked to input data on product sales of PT. XYZ in previous years in excel format.

2. After the input process is complete, the application process the inputted excel data, and then the data is stored in the database.

3. The Administrator then moves to the sales prediction menu, and the Administrator fills in the parameters needed so that the data can be trained

4. Then click the Perform Training button to start training the data and get the best prediction calculation weights.

5. After finding the best weight value, the Administrator enters the Sales Prediction Results menu, clicks the calculate prediction button to calculate the predicted sales results for PT. XYZ in the future 
6. After the counting process is complete, the results of hem brediction of sales at PT. XYZ in the future.

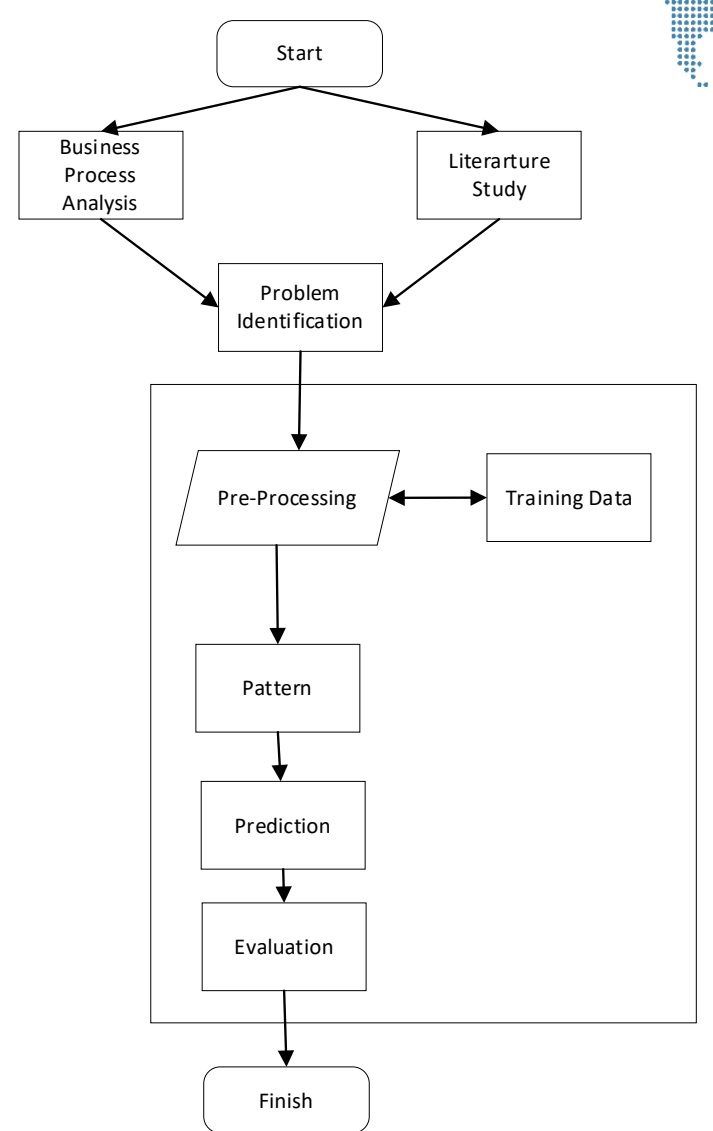

Figure 1. Research Methodology

Then Process how the software works for the owner:

1. Owners are asked to input data on product sales of PT. XYZ in previous years already in excel format.

2. After the input process is complete, the application process the inputted excel data, and then the data is stored in the database.

3. The owner selects the Sales Prediction Results menu, clicks the calculate prediction button to calculate the predicted sales results for PT. XYZ in the future.

4. After the counting process is complete, it displayed the prediction results of product sales of PT. XYZ in the future.

So that it is functional in the application, described in the table below

Table 1. Functional Requirement

\begin{tabular}{|c|c|l|}
\hline No & $\begin{array}{c}\text { Functional } \\
\text { Requirement }\end{array}$ & \multicolumn{1}{c|}{ Description } \\
\hline KF01 & Login & $\begin{array}{l}\text { Owners and users use it to use the features in the sales } \\
\text { prediction application by entering the specified } \\
\text { username and password data. }\end{array}$ \\
\hline KF02 & Data Import & $\begin{array}{l}\text { Owners and administrators use it to initiate data for } \\
\text { training data and test data before normalizing the data } \\
\text { first and then saving it to the database. }\end{array}$ \\
\hline
\end{tabular}




\begin{tabular}{|c|c|c|}
\hline No & $\begin{array}{c}\text { Functional } \\
\text { Requirement }\end{array}$ & Descriptionn \\
\hline KF03 & Data Training & $\begin{array}{l}\text { Administrators use them to conduict lraining with } \\
\text { training data taken from the database to get the best } \\
\text { weight with predetermined paramèters, namely } \\
\text { learning rate, max epoch, hidden layer, and target } \\
\text { error. }\end{array}$ \\
\hline KF04 & Data Testing & $\begin{array}{l}\text { Administrators perform tests with test data taken from } \\
\text { the database and calculate the prediction results' } \\
\text { accuracy value. }\end{array}$ \\
\hline KF05 & Prediction Output & $\begin{array}{l}\text { Owners and administrators used them to see the } \\
\text { predicted results of future sales. }\end{array}$ \\
\hline
\end{tabular}

\section{Result and Discussion}

Use Case Diagram is a textual and graphic description of how the system or software functions from the user's point of view.[25] In this use, the case will be known what functions are in the system created. An Entity-Relationship (ER) Diagram used to illustrate how "entities" such as people, objects, or concepts relate to each other within a system of prediction of sales

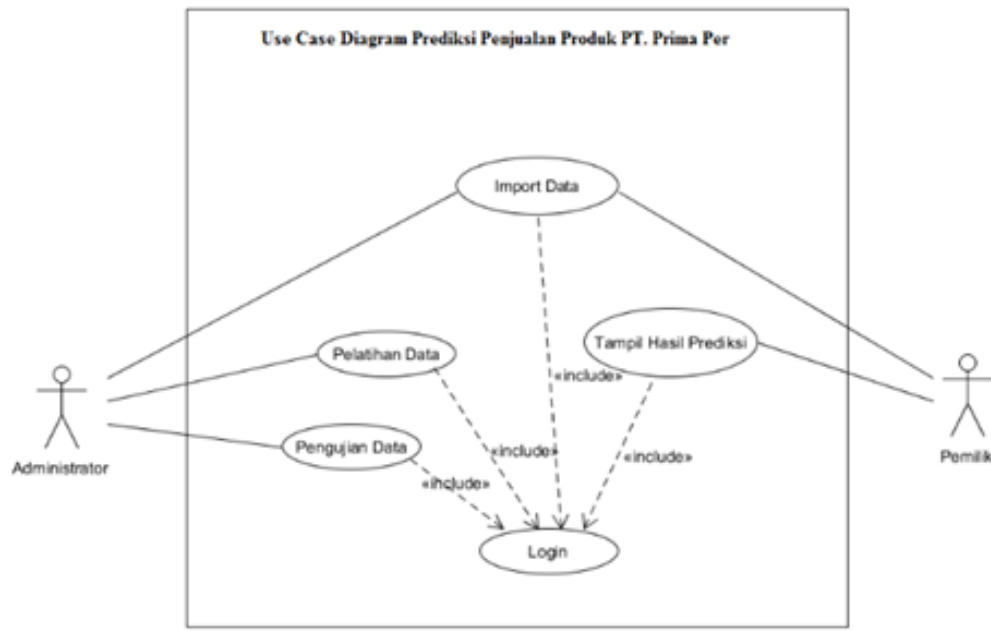

Figure 2. Use Case Diagram of Forecast Sales PT XYZ

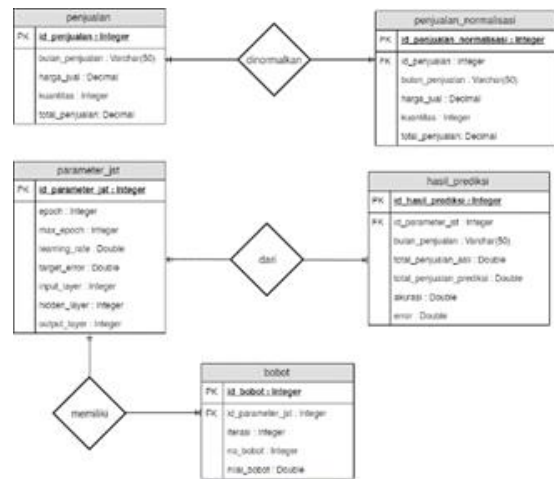

Figure 3. Entity Relationship Diagram of Forecast Sales PT XYZ

The implementation of functional requirements is made on one page called the prediction page. On this page, there are sub-pages of data import, sales prediction, and sales prediction results. A document select menu on the data import page where previous sales data in .xls format can be entered and saved into the database. On the sales 


\section{asinta}

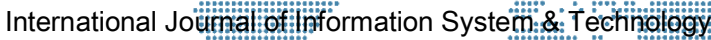

prediction page, two tables will be formed. The first table is the preyious sales coutat that has not been normalized, and the second table is the normalized saleses data.

Prediction steps, the data training parameters must be filled in first with an explanation of the parameters, namely the learning rate is a parameter to calculate the weight correction value when the training process is filled with a number range from 0.1 to 1 . The hidden layer is a hidden layer between the input and output layers. This serves to assist the data training process, the more hidden layers used, the better the output obtained, but the data training time will be longer. Max Epoch is the maximum number of epochs carried out in a data training (1 epoch is a series of Artificial Neural Network learning). Target Error is the error value determined in one data training where the smaller the error value, the longer the data training process is carried out. Then if the button does the training is clicked, then the data training process carried out. The length of the data training process depends on the specifications of the hardware used. After the data training is completed, the parameters stored in the parameter select menu. To make a prediction, select the parameters made previously, select ok and select the calculate prediction button. The prediction results displayed on the sales prediction results page. The image in UI-01 consists of three images. Figure UI-01a is an implementation of the data import interface design.

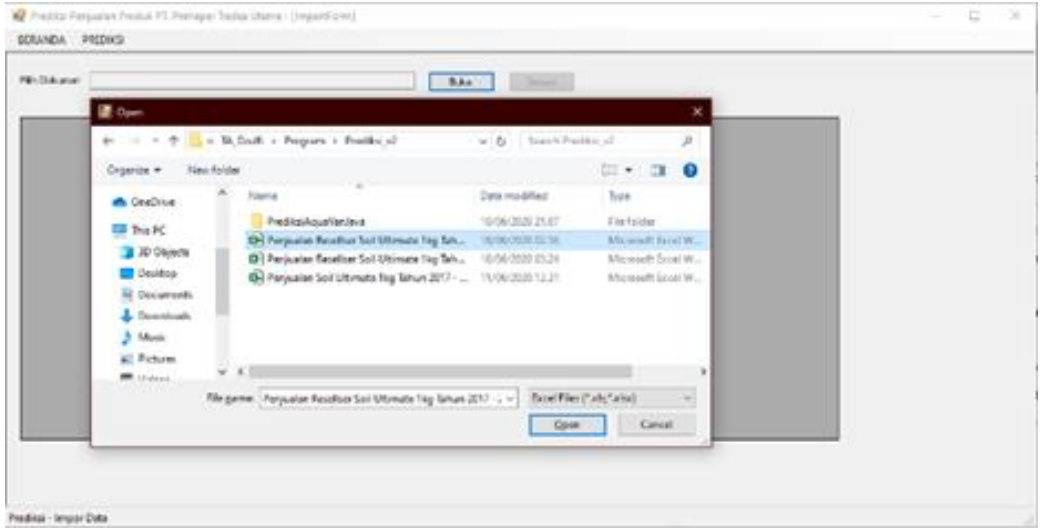

Figure 4. Data Import Page [UI-01a]

Figure UI-01b is an implementation of the sales prediction interface design. The graphic shows how data from CSV are import to the application.

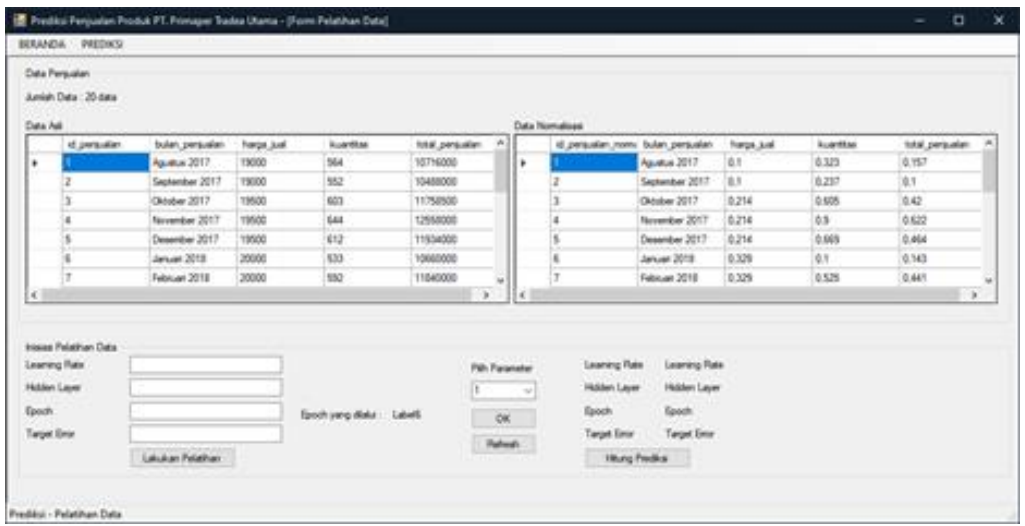

Figure 5. Sales Prediction Interface [UI-01b]

The UI-01c image is an implementation of the sales prediction result interface. The graphic shows how to process the prediction based on data imported. In this feature, first step data trained is used to create a prediction. Results show the figure below. 


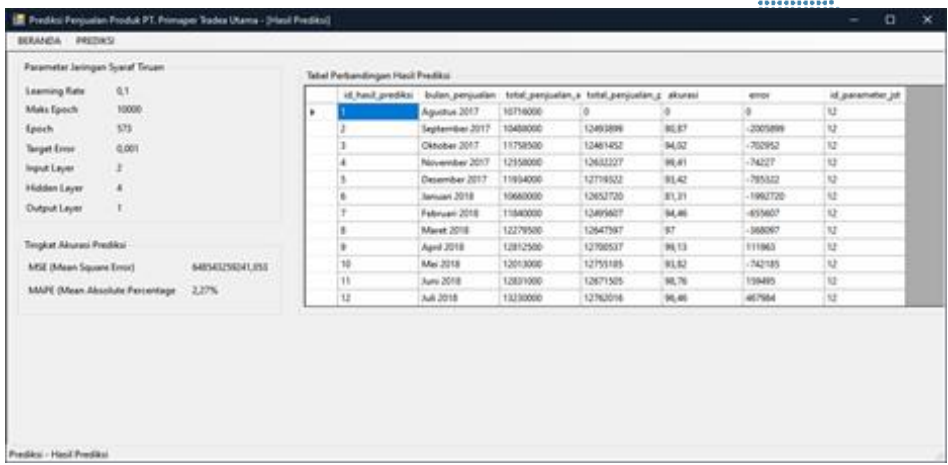

Figure 6. Sales Prediction Result Page [UI-01c]

After the prediction result came out, two tests were carried out: testing the backpropagation algorithm and testing the software function. A trial process was carried out in testing this method to apply PT XYZ product sales prediction using the Artificial Neural Network backpropagation method. The trial was conducted to determine the accuracy of the application made in providing predictions on the sales of PT XYZ products in the following month. In this Artificial Neural Network backpropagation method, to predict PT XYZ products in the following month, the first step is to determine the number of input layers, the number of hidden layers, and the number of output layers. The number of input layers is 2 , which represents each variable from the selling price of the product and the number of goods sold, then the hidden layer itself determined after experiments with 3,4 , and 5 layers, for the output layer, there is 1 which represents the total sales variable.

Table 2. Initiation Input Layer

\begin{tabular}{|l|l|l|}
\hline No & Total Variable Sales & Inisiation Layer Input \\
\hline 1 & Selling Price & $\mathrm{X} 1$ \\
\hline 2 & Quantity (number) & $\mathrm{X} 2$ \\
\hline
\end{tabular}

The following steps determine the training data that used in the program as it is known that Artificial Neural Network backpropagation trains the network to get a balance between the network's ability to recognize the patterns used during training and the network's ability to respond correctly to input patterns that are similar (not the same) to the patterns used during training. For this reason, training data is needed that is used in the program to study patterns. The sales training data is as follows:

Table 3. Data Training

\begin{tabular}{|c|c|c|c|c|c|}
\hline No & Month & & $\mathbf{X}_{1}$ & $\mathbf{X}_{2}$ & Target \\
\hline 1 & Agustus 2017 & $\mathrm{Rp}$ & 190.000 & 564 & Rp 107.160.000 \\
\hline 2 & September 2017 & $\mathrm{Rp}$ & 190.000 & 552 & Rp 104.880 .000 \\
\hline 3 & Oktober 2017 & $\mathrm{Rp}$ & 195.000 & 603 & Rp 117.585 .000 \\
\hline 4 & November 2017 & $\mathrm{Rp}$ & 195.000 & 644 & $\operatorname{Rp} 125.580 .000$ \\
\hline 5 & Desember 2017 & $\mathrm{Rp}$ & 195.000 & 612 & Rp 119.340 .000 \\
\hline 6 & Januari 2018 & $\mathrm{Rp}$ & 200.000 & 533 & Rp 106.600 .000 \\
\hline 7 & Februari 2018 & $\mathrm{Rp}$ & 200.000 & 592 & $\operatorname{Rp} 118.400 .000$ \\
\hline 8 & Maret 2018 & $\mathrm{Rp}$ & 205.000 & 599 & Rp 122.795 .000 \\
\hline 9 & April 2018 & $\mathrm{Rp}$ & 205.000 & 625 & $\mathrm{Rp} 128.125 .000$ \\
\hline 10 & Mei 2018 & $\mathrm{Rp}$ & 205.000 & 586 & Rp 120.130 .000 \\
\hline 11 & Juni 2018 & $\mathrm{Rp}$ & 210.000 & 611 & $\mathrm{Rp} 128.310 .000$ \\
\hline 12 & Juli 2018 & $\mathrm{Rp}$ & 210.000 & 630 & Rp 132.300 .000 \\
\hline
\end{tabular}




\begin{tabular}{|c|c|c|c|c|c|}
\hline No & Month & & $\mathbf{X}_{1}$ & $\mathbf{X}_{2}$ & Targetet \\
\hline 13 & Agustus 2018 & $\mathrm{Rp}$ & 210.000 & 597 & Rp $125.37 \mathrm{fog}$ \\
\hline 14 & September 2018 & $\mathrm{Rp}$ & 210.000 & 618 & Rp 129.780000 \\
\hline 15 & Oktober 2018 & $\mathrm{Rp}$ & 220.000 & 621 & Rp 136.620.000 \\
\hline 16 & November 2018 & $\mathrm{Rp}$ & 220.000 & 598 & Rp 131.560 .000 \\
\hline
\end{tabular}

After that, determine the test data used in the Artificial Neural Network backpropagation method to predict the sales of PT XYZ products for the next month.

Table 4. Data Testing per Month

\begin{tabular}{|c|l|ll|c|c|}
\hline No & \multicolumn{1}{|c|}{ Month } & & $\mathbf{X}_{\mathbf{1}}$ & $\mathbf{X}_{\mathbf{2}}$ & Target \\
\hline 1 & Desember 2018 & $\mathrm{Rp}$ & 220.000 & 580 & $\mathrm{Rp} \mathrm{127.600.000}$ \\
\hline 2 & Januari 2019 & $\mathrm{Rp}$ & 220.000 & 576 & $\mathrm{Rp} \mathrm{126.720.000}$ \\
\hline 3 & Februari 2019 & $\mathrm{Rp}$ & 225.000 & 590 & $\mathrm{Rp} 132.750 .000$ \\
\hline 4 & Maret 2019 & $\mathrm{Rp}$ & 225.000 & 603 & $\mathrm{Rp} \mathrm{135.675.000}$ \\
\hline
\end{tabular}

Furthermore, the determination of the appropriate initial weights, learning rates, and hidden layers for applying Artificial Neural Network with the backpropagation method predict PT XYZ products' sales per month. Therefore, a test case was made to determine the number of epochs passed and the actual error results. In making one able io test case, the initial weight determination is done by randomizing the numbers between 0.1 to 0.9 . Experiments were carried out by changing the learning rate from $0.1,0.3,0.5,0.7$, and the maximum number of epochs achieved by the program. Each learning rate has experimented with 3, 4, and 5 hidden layers. The results of the able io test case can be seen in table five.

Table 5. Test Case Scenario

\begin{tabular}{|c|l|l|l|l|}
\hline $\begin{array}{c}\text { Learning } \\
\text { Rate }\end{array}$ & $\begin{array}{c}\text { Hidden } \\
\text { Layer }\end{array}$ & $\begin{array}{c}\text { Total } \\
\text { Epoch }\end{array}$ & $\begin{array}{c}\text { Maksimal } \\
\text { Epoch }\end{array}$ & $\begin{array}{c}\text { Target } \\
\text { Error }\end{array}$ \\
\hline \multirow{4}{*}{0.1} & 3 & 1000 & 1000 & 0.001 \\
\cline { 2 - 5 } & 4 & 400 & 1000 & 0.001 \\
\cline { 2 - 5 } & 5 & 893 & 1000 & 0.001 \\
\hline \multirow{3}{*}{0.3} & 3 & 350 & 1000 & 0.001 \\
\cline { 2 - 5 } & 4 & 354 & 1000 & 0.001 \\
\cline { 2 - 5 } & 5 & 204 & 1000 & 0.001 \\
\hline \multirow{3}{*}{0.5} & 3 & 237 & 1000 & 0.001 \\
\cline { 2 - 5 } & 4 & 110 & 1000 & 0.001 \\
\cline { 2 - 5 } & 5 & 150 & 1000 & 0.001 \\
\hline \multirow{3}{*}{0.7} & 3 & 140 & 1000 & 0.001 \\
\cline { 2 - 5 } & 4 & 97 & 1000 & 0.001 \\
\cline { 2 - 5 } & 5 & 77 & 1000 & 0.001 \\
\hline
\end{tabular}

From table 5 , it can be seen that, for a learning rate with a value above 0.5 , the number of epochs passed to reach or approach the target error is decreasing, and for a learning rate below 0.5 , the number of epochs passed to reach the target error is increasing. Next, the data in table four were tested with the results from the test case table in table five. The results of data testing can be seen in table sixth below.

Table 6. The results of data testing

\begin{tabular}{|c|c|l|c|c|c|}
\hline $\begin{array}{c}\text { Learning } \\
\text { Rate }\end{array}$ & $\begin{array}{c}\text { Hidden } \\
\text { Layer }\end{array}$ & Bulan Penjualan & Target Aktual & $\begin{array}{c}\text { Target } \\
\text { Prediksi }\end{array}$ & Error \\
\hline \multirow{2}{*}{0.1} & \multirow{2}{*}{3} & Desember 2018 & 127.600 .000 & 110.013 .255 & 17.586 .745 \\
\cline { 3 - 6 } & & Januari 2019 & 126.720 .000 & 109.518 .008 & 17.201 .992 \\
\cline { 3 - 6 } & & Februari 2019 & 132.750 .000 & 109.398 .465 & 23.351 .535 \\
\hline
\end{tabular}




\begin{tabular}{|c|c|c|c|c|c|}
\hline \multirow{3}{*}{$\begin{array}{c}\text { Learning } \\
\text { Rate }\end{array}$} & \multirow{3}{*}{$\begin{array}{c}\text { Hidden } \\
\text { Layer }\end{array}$} & \multicolumn{3}{|r|}{ 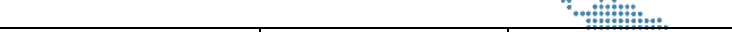 } & \multirow{2}{*}{ 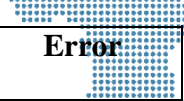 } \\
\hline & & Bulan Penjualan & Target Aktual & 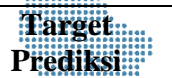 & \\
\hline & & Maret 2019 & 135.675 .000 & $110: 248: 85$ & $25.456: 815$ \\
\hline & \multirow{4}{*}{4} & Desember 2018 & 127.600 .000 & 12942.978 & $-1.522: 978$ \\
\hline & & Januari 2019 & 126.720 .000 & 128.832 .660 & -2.112 .660 \\
\hline & & Februari 2019 & 132.750 .000 & 128.764 .350 & 3.985 .650 \\
\hline & & Maret 2019 & 135.675 .000 & 129.242 .520 & 6.432 .480 \\
\hline & \multirow{4}{*}{5} & Desember 2018 & 127.600 .000 & 132.436 .013 & -4.836 .013 \\
\hline & & Januari 2019 & 126.720 .000 & 132.162 .773 & -5.442 .773 \\
\hline & & Februari 2019 & 132.750 .000 & 132.094 .463 & 655.537 \\
\hline & & Maret 2019 & 135.675 .000 & 132.640 .943 & 3.034 .057 \\
\hline \multirow{9}{*}{0.3} & \multirow{4}{*}{3} & Desember 2018 & 127.600 .000 & 128.303 .258 & -703.258 \\
\hline & & Januari 2019 & 126.720 .000 & 128.217 .870 & -1.497 .870 \\
\hline & & Februari 2019 & 132.750 .000 & 128.200 .793 & 4.549 .207 \\
\hline & & Maret 2019 & 135.675 .000 & 128.644 .808 & 7.030 .192 \\
\hline & \multirow{4}{*}{4} & Desember 2018 & 127.600 .000 & 121.557 .645 & 6.042 .355 \\
\hline & & Januari 2019 & 126.720 .000 & 121.164 .863 & 5.555 .137 \\
\hline & & Februari 2019 & 132.750 .000 & 121.079 .475 & 11.670 .525 \\
\hline & & Maret 2019 & 135.675 .000 & 121.694 .265 & 13.980 .735 \\
\hline & 5 & Desember 2018 & 127.600 .000 & 143.895 .015 & -16.295 .015 \\
\hline \multirow{3}{*}{0.3} & \multirow{3}{*}{5} & Januari 2019 & 126.720 .000 & 143.485 .155 & -16.765 .155 \\
\hline & & Februari 2019 & 132.750 .000 & 143.399 .768 & -10.649 .768 \\
\hline & & Maret 2019 & 135.675 .000 & 143.963 .325 & -8.288 .325 \\
\hline \multirow{12}{*}{0.5} & \multirow{4}{*}{3} & Desember 2018 & 127.600 .000 & 112.301 .640 & 15.298 .360 \\
\hline & & Januari 2019 & 126.720 .000 & 112.165 .020 & 14.554 .980 \\
\hline & & Februari 2019 & 132.750 .000 & 112.130 .865 & 20.619 .135 \\
\hline & & Maret 2019 & 135.675 .000 & 112.404 .105 & 23.270 .895 \\
\hline & \multirow{4}{*}{4} & Desember 2018 & 127.600 .000 & 145.090 .440 & -17.490 .440 \\
\hline & & Januari 2019 & 126.720 .000 & 144.765 .968 & -18.045 .968 \\
\hline & & Februari 2019 & 132.750 .000 & 144.697 .658 & -11.947 .658 \\
\hline & & Maret 2019 & 135.675 .000 & 145.158 .750 & -9.483 .750 \\
\hline & \multirow{4}{*}{5} & Desember 2018 & 127.600 .000 & 145.346 .603 & -17.746 .603 \\
\hline & & Januari 2019 & 126.720 .000 & 144.987 .975 & -18.267 .975 \\
\hline & & Februari 2019 & 132.750 .000 & 144.902 .588 & -12.152 .588 \\
\hline & & Maret 2019 & 135.675 .000 & 145.397 .835 & -9.722 .835 \\
\hline \multirow{12}{*}{0.7} & \multirow{4}{*}{3} & Desember 2018 & 127.600 .000 & 119.849 .895 & 7.750 .105 \\
\hline & & Januari 2019 & 126.720 .000 & 119.405 .880 & 7.314 .120 \\
\hline & & Februari 2019 & 132.750 .000 & 119.303 .415 & 13.446 .585 \\
\hline & & Maret 2019 & 135.675 .000 & 120.242 .678 & 15.432 .322 \\
\hline & \multirow{4}{*}{4} & Desember 2018 & 127.600 .000 & 146.815 .268 & -19.215 .268 \\
\hline & & Januari 2019 & 126.720 .000 & 146.627 .415 & -19.907 .415 \\
\hline & & Februari 2019 & 132.750 .000 & 146.576 .183 & -13.826 .183 \\
\hline & & Maret 2019 & 135.675 .000 & 146.917 .733 & -11.242 .733 \\
\hline & \multirow{4}{*}{5} & Desember 2018 & 127.600 .000 & 137.405 .565 & -9.805 .565 \\
\hline & & Januari 2019 & 126.720 .000 & 136.995 .705 & -10.275 .705 \\
\hline & & Februari 2019 & 132.750 .000 & 136.910 .318 & -4.160 .318 \\
\hline & & Maret 2019 & 135.675 .000 & 137.405 .565 & -1.730 .565 \\
\hline
\end{tabular}

From table sixth, it can be seen that the prediction target that is almost close to the actual target is in the test case scenario with a learning rate of 0.1 and hidden layer 4 . So from table five, it is determined that for testing the prediction of PT XYZ product sales with a learning rate of 0.1 and hidden layer 4 . The results of the prediction calculations as follows:

Table 7. Prediction Results from Selected Test Cases

\begin{tabular}{|l|r|r|r|r|}
\hline \multicolumn{1}{|c|}{ Month } & Total Sales & \multicolumn{1}{c|}{$\begin{array}{l}\text { Total Sales } \\
\text { Prediction }\end{array}$} & \multicolumn{1}{c|}{$\begin{array}{c}\text { Accuration } \\
(\text { \%) }\end{array}$} & \multicolumn{1}{c|}{ Error } \\
\hline Agustus 2017 & Rp107.160.000 & & 0 & - \\
\hline September 2017 & Rp104.880.000 & Rp126.697.973 & 80,2 & - Rp21.817.973 \\
\hline Oktober 2017 & Rp117.585.000 & Rp126.424.733 & 92,48 & - Rp8.839.733 \\
\hline November 2017 & Rp125.580.000 & Rp127.825.088 & 98,21 & - Rp2.245.088 \\
\hline
\end{tabular}




\begin{tabular}{|c|c|c|c|c|}
\hline Month & Total Sales & $\begin{array}{l}\text { Total Sales } \\
\text { Prediction }\end{array}$ & $\begin{array}{l}\text { Acenturion } \\
\text { (*) }\end{array}$ & Error \\
\hline Desember 2017 & Rp119.340.000 & Rp128.559.420 & 42827 & 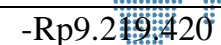 \\
\hline Januari 2018 & Rp106.600.000 & Rp127.978.785 & $9 ; 94$ & -Rp21.378.786 \\
\hline Februari 2018 & Rp118.400.000 & Rp126.697.973 & 92,99 & -Rp8.297.973 \\
\hline Maret 2018 & Rp122.795.000 & Rp127.910.475 & 95,83 & -Rp5.115.475 \\
\hline April 2018 & Rp128.125.000 & Rp128.337.413 & 99,83 & -Rp212.413 \\
\hline Mei 2018 & Rp120.130.000 & Rp128.781.428 & 92,8 & -Rp8.651.428 \\
\hline Juni 2018 & Rp128.310.000 & Rp128.098.328 & 99,84 & Rp211.672 \\
\hline Juli 2018 & Rp132.300.000 & Rp128.815.583 & 97,37 & Rp3.484.417 \\
\hline Agustus 2018 & Rp125.370.000 & Rp129.122.978 & 97,01 & -Rp3.752.978 \\
\hline September 2018 & Rp129.780.000 & Rp128.576.498 & 99,07 & Rp1.203.502 \\
\hline Oktober 2018 & Rp136.620.000 & Rp128.935.125 & 94,38 & Rp7.684.875 \\
\hline November 2018 & Rp131.560.000 & Rp129.481.605 & 98,42 & Rp2.078.395 \\
\hline Desember 2018 & Rp127.600.000 & Rp129.122.978 & 98,81 & -Rp1.522.978 \\
\hline Januari 2019 & Rp126.720.000 & Rp128.832.660 & 98,33 & -Rp2.112.661 \\
\hline Februari 2019 & Rp132.750.000 & Rp128.764.350 & 97 & Rp3.985.650 \\
\hline Maret 2019 & Rp135.675.000 & Rp129.242.520 & 95,26 & Rp6.432.480 \\
\hline April 2019 & & Rp129.447.450 & & \\
\hline
\end{tabular}

Table seven shows that the average accuracy of the prediction application for PT XYZ product sales is $97 \%$, with MAPE $=3.35 \%$.

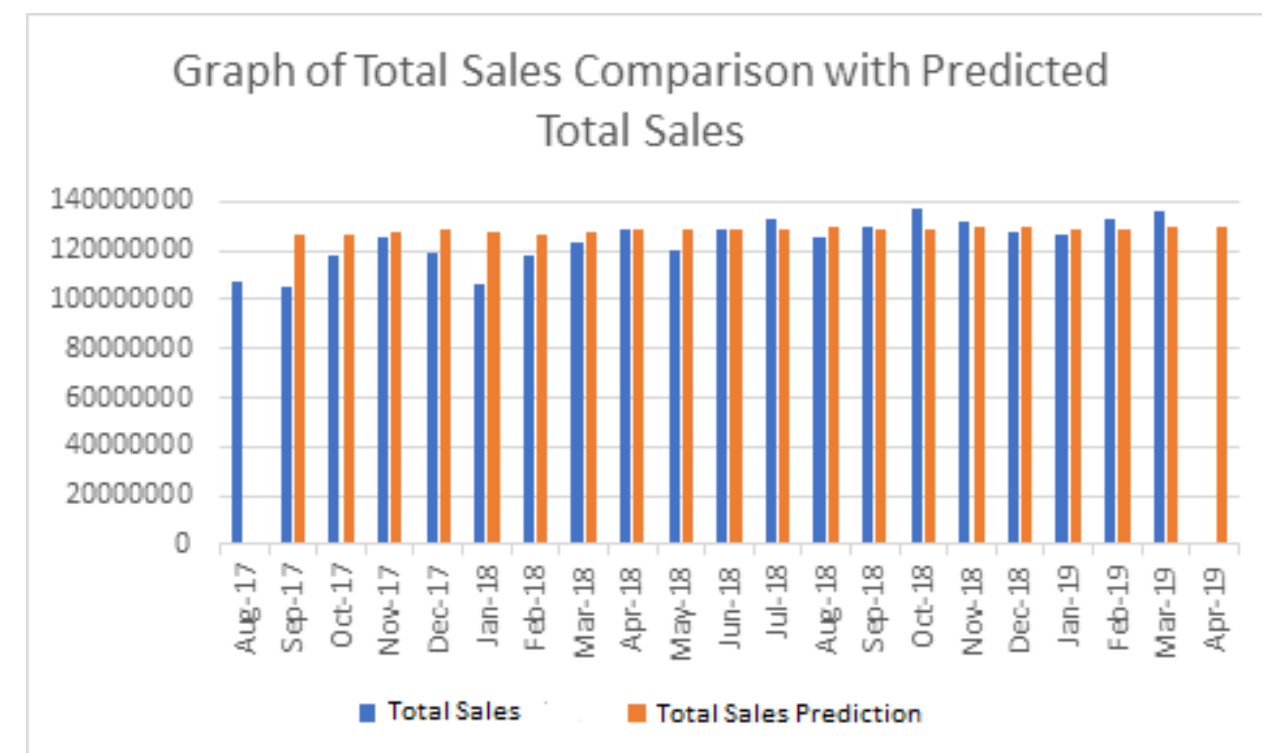

Figure 7. Total Sales Comparison with Predicted Total Sales

Testing on the software functions built in this study used the black box testing method. This method focuses on the functionality of the application to be built. Testing is done based on the use case that has been made. Based on the results of implementation and testing in this study, it can be concluded that the implementation of PT XYZ product sales forecasting using Artificial Neural Network was successfully implemented with an average forecasting accuracy of $97 \%$. Based on the discussion that has been described in the previous chapter, suggestions that can be given for the development of sales predictions for PT XYZ products are as follows:

a) They applied methods to initiate initial weights, not to use random numbers such as the Genetic Algorithm or the Nguyen method.

b) Add attributes for product sales data such as stock, damaged goods, and returned goods. 


\section{asinta ${ }^{(4)}$}

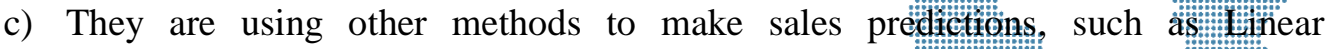
Regression.

\section{References}

[1] Pebrianasari, Edy, dkk, 2015, "Analisis Pengenalan Motif Batik Pekalongan Menggunakan Algoritma ackpropagation", Techno.COM Universitas Dian Nuswantoro.Shazmeen, S.F.,

[2] Fausett, L, 1994, "Fundamental of Neural Network, Architecture, Algorithms, and Applications", Prentice-Hall.

[3] Sharma, Nijhawan, 2015, "Rainfall Prediction Using Neural Network", International Journal of Computer Science Trends and Technology 3(3): 65-69.

[4] Siang, J. J, 2009, “Artificial Neural Network dan Pemogramannya Menggunakan MATLAB", ANDI.

[5] Baig, M.M.A. \& Pawar, M.R., 2013. Performance Evaluation of Different Data Mining Classification Algorithm and Predictive Analysis. IOSR Journal of Computer Engineering, 10(6), pp.1-6.

[6] Jain, V., Narula, G.S. \& Singh, M., 2013. Implementation of Data Mining in Online Shopping System using Tanagara Tool. International Journal of Computer Science and Engineering, 2(1), pp.47-58.

[7] Sahu, H., Shrma, S. \& Gondhalakar, S., 2011. A Brief Overview of Data Mining Survey. International Journal of Computer Technology and Electronics Engineering, 1(3), pp.114-21.

[8] Lee, Choi, 2013, "A Multi-Industry Bankruptcy Prediction Model using BackPropagation Neural Network and Multivariate Discriminant Analysis", Expert Systems with Applications 40(8): 2941-2946

[9] Subagyo, Pangestu, 1986, "Forecasting Konsep dan Aplikasi", BPFE UGM Yogyakarta.

[10] Redjeki, Sri, 2013, "Perbandingan Algoritma Backpropagation dan K-Nearest Neighbor (K-NN) untuk Identifikasi Penyakit", Seminar Nasional Aplikasi Teknologi Informasi STMIK AMIKOM.

[11] Makridakis, Spyros, dkk, 1993, "Metode Dan Aplikasi Peramalan Edisi ke II". Erlangga

[12] Park, Kang,2007, "Prediction of Fatigue Life for Spot Welds using BackPropagation Neural Networks."

[13] Prasetyo, E, 2014, "Data Mining Mengolah Data Menjadi Informasi Menggunakan Matlab"

[14] Sommerville, Ian, 2011, "Software Engineering", Pearson.

[15] Sugiyono, 2014, "Metode Penelitian Pendidikan Pendekatan Kuantitatif, Kualitatif, dan R\&D, Alfabeta

[16] Sugiyono, 2014, "Metode Penelitian Pendidikan Pendekatan Kuantitatif, Kualitatif, dan R\&D 